\title{
Comparative assessment of wellbeing of Chrysichthys filamentosus, Kribia nana and Pegusa lascaris from Tomaro, Ajegunle and Badagry Creeks in Lagos, Nigeria
}

\author{
GABRIEL OLARINDE MEKULEYI*, ABUBAKAR JERMA YAJI ${ }^{1}$ \\ AND FOLAKE IREWUNMI ADELERE ${ }^{2}$ \\ Department of Fisheries, Lagos State University, Lagos, Nigeria \\ ${ }^{1}$ Department of Fisheries, Modibbo Adama University of Technology, Adamawa State, Nigeria \\ ${ }^{2}$ Environmental Biology Unit, Department of Science and Laboratory Technology, School of Pure and \\ Applied Sciences, Ogun State Institute of Technology, Igbesa, Ogun State, Nigeria \\ *Corresponding Author: gabrielmekuleyi@gmail.com
}

\begin{abstract}
An investigation was made from April to September 2018 to detect some metals (cadmium, chromium, copper, iron, lead and zinc) in the fishes like Kribia nana, Chrysichthys filamentosus and Pegusa lascaris, as well as in water and sediment from three creeks i.e. Badagry (Station 1), Tomaro (Station 2) and Ajegunle (Station 3) in Lagos, Nigeria. Samples were collected and analyzed according to standard methods. Most of the water quality parameters are within standard recommended limits. Iron content in $C$. filamentosus $(11.57 \pm 2.50 \mathrm{mg} / \mathrm{kg})$ from station 3 was higher $(p<0.05)$ than iron content from station $2(6.54 \pm 2.88 \mathrm{mg} / \mathrm{kg})$, while iron content in $K$. nana $(8.34 \pm 1.10 \mathrm{mg} / \mathrm{kg})$ from station 3 was higher $(p<0.05)$ than that from station 1 $(6.12 \pm 1.04 \mathrm{mg} / \mathrm{kg})$ and station $2(3.62 \pm 1.14 \mathrm{mg} / \mathrm{kg})$ respectively. Zinc $(5.54 \pm 1.12 \mathrm{mg} / \mathrm{kg})$ recorded from station 3 was significantly $(p<0.05)$ higher than that from station $2(2.45 \pm 0.96 \mathrm{mg} / \mathrm{kg})$ and station 1 $(3.84 \pm 0.86 \mathrm{mg} / \mathrm{kg})$. Iron content in all the fishes, cadmium in $C$. filamentosus and lead, chromium, copper in $K$. nana in stations 1 and 3 exceeded permissible limits. Condition factor $(\mathrm{K})$ of most fish species was greater than 1. The Hazardous Index (HI) content in $C$. filamentosus from the three creeks and $K$. nana from stations 1 and 3 was above 1. Ecological risk factor(Er), enrichment factors (EF) and Index of geo-accumulation indicated moderate contamination of the sediment with cadmium. In conclusion, the three creeks are moderately polluted with metals but consumption of large quantity of the fish species could have high health risk. Hence, discharge of untreated metals into the water should be precluded.

Keywords: Metals, Pollution, Kribia nana, Chrysichthys filamentosus, Pegusa lascaris
\end{abstract}

\section{Introduction}

Fish is a very essential food source for human being. This is because fish provides Omega 3 fatty acids, vitamins, minerals and protein. Despite fish nutritional capability, consumption of fish contaminated with heavy metals brings hazard concentration concern for human consumer (Olowu et al. 2010). Heavy metals are high priority pollutants because of their relatively toxic and persistent nature in the environment (Wangboje and Ekundayo 2013). Apart from disrupting the aquatic environment, the biological amplification of these toxic metals in the aquatic food chain constitutes a serious threat to public health (Ndimele 2012). Indeed, Badagry Division of Lagos Western-Nigeria is blessed with several inland waters. These waters include Tomaro, Ajegunle and Badagry creeks. Recent study carried out by Ejike and Liman (2017) and Mekuleyi et al. (2019) revealed that Nigerian water bodies needs to be assessed periodically as a result of heavy metal pollution. To the best of our knowledge, no comparative study on the status of Kribia nana, Pegusa lascaris and Chrysichthys filamentosus from these three creeks has been reported. It is on this background that this study aimed to compare the condition factor (k) and length-weight relationship of Kribia nana , Pegusa lascaris and Chrysichthys filamentosus

https://doi.org/10.52168/bjf.2021.33.01 
with a view to determine their wellness in the selected water bodies. The study also examined levels of some heavy metals in the selected fishes, water, and sediment from Tomaro, Ajegunle and Badagry Creeks in Lagos, Nigeria in order to determine their safety for human use and consumption.

\section{Materials and Methods}

Study area/ sampling stations: This study was carried out in Lagos State, Nigeria on three water bodies (Badagry Creek, Tomaro Creek and Ajegunle Creek) as presented in Fig. 1. These three sampling stations were selected as a result of their economic importance to Lagosian. Station 2 (Tomaro creek) is on Longitude $3^{\circ} 21^{\prime} 7.352 " \mathrm{E}$ and Latitude $6^{\circ} 27^{\prime} 0.520^{\prime \prime} \mathrm{N}$ whose water drains into the Lagos lagoon through the Apapa wharf (Nwankwo et al. 2013) while station 1(Badagry creek) and station 3 (Ajegunle creek) lies between longitude $2^{0} 42^{1} \mathrm{E}$ and $3^{0}$ $22^{1} \mathrm{E}$ and between latitude $6^{0} 22^{1} \mathrm{~N}$ and $6^{0} 42^{1} \mathrm{~N}$ (Mekuleyi et al. 2019). They are bounded in the south by the Atlantic Ocean. Also, in the north, they are bounded by Alimosho Local Government Area but enclosed in the east by Apapa Local Government Area (Mekuleyi et al., 2019). Specifically, sampling stations 2, 3 and 1 respectively are located in Apapa Local Government, Ajeromi-Ifelodun Local Government, and Badagry Local Government of Lagos State, Nigeria.

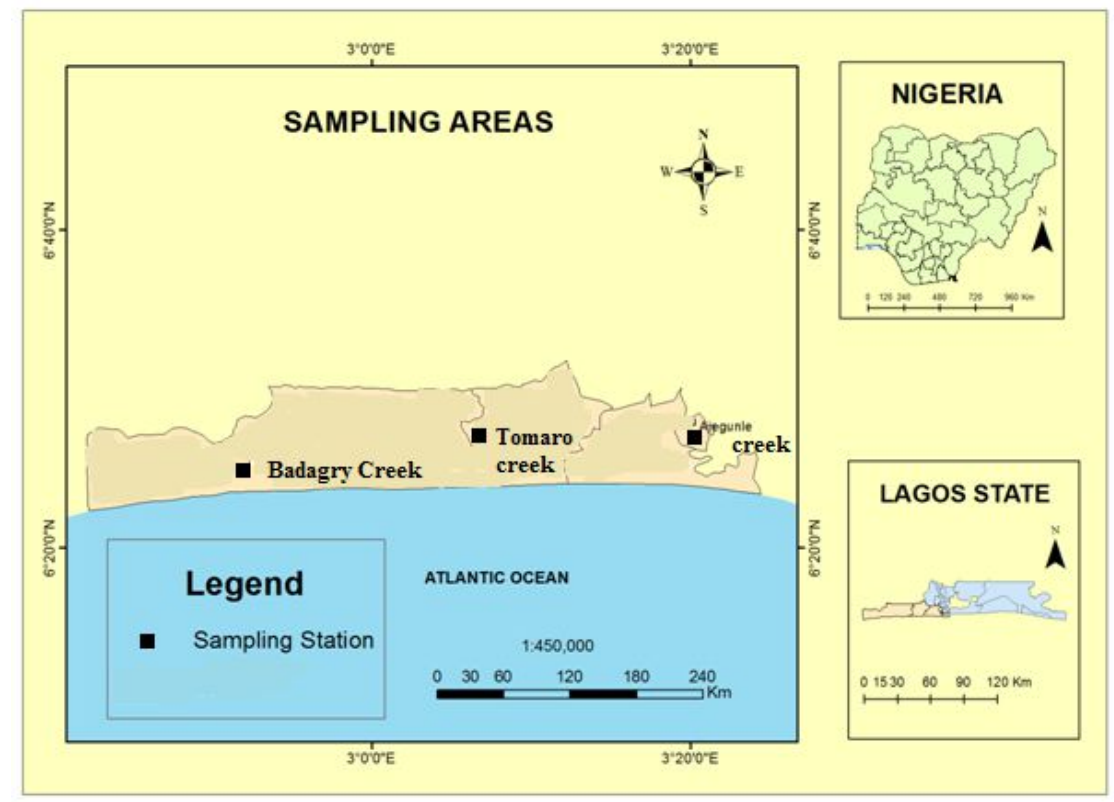

Fig. 1. Location of Badagry Creek, Tomaro Creek and Ajegunle Creek in Lagos State, Nigeria.

Collection of fish, water and sediment samples: A total of 270 fish specimens consisting 90 samples of Kribia nana, Chrysichthys filamentosus, and Pegusa lascaris respectively from each creek were purchased from the landing sites of stations 1- 3 between April and September 2018. Specimens were identified in the laboratory by experts at the Department of Fisheries, Lagos State University while samples of water and sediment were also collected for six months following APHA (1998). 
Measurement of weight, length, and length - weight relationship and condition factor of fish samples: By using electric balance, body weight of the fish was measured to the nearest 0.1 $\mathrm{g}$, while the total length was measured with measuring board to the nearest $0.1 \mathrm{~cm}$. The length and weight (LWR) relationship of the fish samples were calculated using the equation $\mathrm{W}=\mathrm{aL}^{b}$ (Pauly 1983). The values of constant $\mathrm{a}$ and $\mathrm{b}$ were determined via the least-square method applied to the $\log$ transformed data as $\log W=\log a+b \log L$ (Pauly 1983) where W (g) is the body weight of the fish, $\mathrm{L}(\mathrm{cm})$ is the total length, $\mathbf{a}$ is the intercept of the regression curve and $\mathrm{b}$ is the regression coefficient. The condition factor $(\mathrm{K})$ was calculated via the formula: $\mathrm{K}=100$ $\mathrm{W} / \mathrm{L}^{3}$ (Pauly 1983). Where $\mathrm{K}=$ condition factor, $\mathrm{W}=$ total body weight $(\mathrm{g}), \mathrm{L}=$ total length (cm).

Determination of physico-chemical parameters: Chemical Oxygen Demand (COD), Carbon dioxide $\left(\mathrm{C}_{2}\right)$, alkalinity, total hardness, and Biochemical Oxygen Demand (BOD) were determined in the laboratory using methods described by APHA (1998). Conductivity, temperature, $\mathrm{pH}$, salinity, Total Dissolved Solid (TDS), and dissolved oxygen of the water samples were measured in-situ by using a mercury-in-glass thermometer, HQ40D Portable Multi Meter (pH, Conductivity, Salinity, TDS, ORP and ISE for water, USA) and DO meter (Method:HACH 8157).

Digestion and analysis of heavy metals: Samples earlier frosted were defrosted at $25^{\circ} \mathrm{C}$ which was attained in $5 \mathrm{~h}$. The digestion of all metals were done and analyzed in accordance with APHA (1998) procedures. The heavy metals (cadmium, chromium, copper, iron, lead and zinc) in water samples were determined in the laboratory using Buck Scientific Atomic Absorption Spectrophotometer (VGP 210 model, USA). Similarly, sediments were dried with crucible for $12 \mathrm{~min}$ and sieved with $0.5 \mathrm{~mm}$ sieve prior to digestion while the metal content of the digested sediment samples was determined using Atomic Absorption Spectrophotometer. Twenty samples of whole fresh $C$. filamentosus, $K$. nana and $P$. lascaris were selected from each sampling station, weighed and oven-dried at $105^{\circ} \mathrm{C}$ for $28 \mathrm{~h}$. Dried samples were grounded into powder with ceramic mortar and pestle and $3 \mathrm{~g}$ of each sample was digested (APHA, 1998). The concentration of the metals was calculated in $\mathrm{mg} / \mathrm{L}$ for water sample and $\mathrm{mg} / \mathrm{kg}$ for sediment and fish specimens (APHA 1998).

Calculation of daily intake (DI) of metals in fish: Copat et al.(2012) divulged that EDI can be calculated using the formula:

$\mathrm{DI}=\underline{\mathrm{EF}_{\mathrm{F}} \mathrm{X} \mathrm{ED}_{\mathrm{D}} \mathrm{X} \mathrm{F}_{\mathrm{IR}} \mathrm{X} \mathrm{C}_{\mathrm{F}} \mathrm{XC} \mathrm{C}_{\mathrm{M}}} \times 10^{-3}$ $\mathrm{W}_{\mathrm{AB}} \mathrm{XT}_{\mathrm{A}}$

Where, $\mathrm{EF}_{\mathrm{F}}=$ Exposure frequency 365 days/year; $\mathrm{ED}_{\mathrm{D}}=$ Exposure duration, equivalent to verge life time (65 years) (Ali and Hau, 2001); $\mathrm{F}_{\mathrm{IR}}=$ Fresh food ingestion rate (g/person/day) being taken as 48/g/person/day (Ali and Hau, 2001); $\mathrm{C}_{\mathrm{F}}=$ Conversion factor $=0.208 ; \mathrm{C}_{M}=$ Heavy metal concentration in the fish stuffs $(\mathrm{mg} / \mathrm{kg} \mathrm{d}-\mathrm{w}) ; \mathrm{W}_{\mathrm{AB}}=$ Average body weight (bw) of consumer (adult) was taken as $60 \mathrm{~kg}$ (Copat et al. 2012); $\mathrm{T}_{\mathrm{A}}=$ Average exposure of time for non-carcinogens which is equal to (EF x ED) as used by Wang et al. (2005).

Calculation of Hazard Quotient (HQ) of metals in fish and Hazard Index(HI) : According to USEPA (1989), HQ is given as: 
COMPARATIVE ASSESSMENT OF WELL-BEING OF C. FILAMENTOSUS, K. NANA AND

P. LASCARIS FROM TOMARO, AJEGUNLE AND BADAGRY CREEKS IN LAGOS, NIGERIA

$$
\mathrm{HQ}=\frac{E D I}{\mathrm{RFDO}}
$$

Where, EDI $=$ Estimated daily intake, RFDO $=$ the reference oral dose of individual metal $(\mathrm{mg} / \mathrm{kg} / \mathrm{day})$.

The hazard index (HI) developed by Guerra et al. (2010) is expressed as:

$\mathrm{HI}=\Sigma \mathrm{HQ}$ of metals

$=\mathrm{HQCd}+\mathrm{HQCr}+\mathrm{HQCu}+\mathrm{HQFe}+\mathrm{HQPb}+\mathrm{HQZn}$

Ecological Risk Factor(Er): Ecological Risk Factor (Er) was calculated according to Hakanson (1980) as $\mathrm{Er}=\operatorname{Tr} \times \mathrm{CF}$

Where, $\operatorname{Tr}$ is the standard toxic-response factor for a given contaminant, and $\mathrm{CF}$ is the contamination factor. Er $<40=$ low potential ecological risk, $40 \leq \mathrm{Er}<80=$ moderate potential ecological risk, $80<\mathrm{Er}<160=$ considerable potential ecological risk, $160 \leq \mathrm{Er}<320=$ high potential ecological risk and $\mathrm{Er} \geq 320=$ very high ecological risk (Hakanson 1980).

Calculation of Contamination Factor, Index of geo-accumulation (IGEO) and Enrichment Factor (EF): These pollution indexes factors were calculated following methods described in Mekuleyi et al. (2019).

Statistical analysis: Excel 2007 was used to compute data for Length-weight relationship of the sampled fish species. In order to determine the kind of allometry exhibited by fish species, slopes of length-weight regressions were compared to 3 using student t- test as opined by (Kumolu-Johnson et al., 2010). Values of metals in the samples across the creeks were computed by SPSS (Version 20) and tested by one-way Analysis of Variance (ANOVA) while Fisher's LSD at $95 \%(p \leq 0.05)$ confidence level was used to separate the means. Also, formulae reported in literatures were used to calculate the pollution indexes.

\section{Results}

Comparison of heavy metals concentration and physico-chemical properties of the creeks: Heavy metal concentrations recorded in water sample at sampling stations 1-3 as shown in Table I were not different. In like trend, parameters like carbon dioxide $\left(\mathrm{CO}_{2}\right)(8.12 \pm 1.64 \mathrm{mg} / \mathrm{L}$, $7.48 \pm 2.15 \mathrm{mg} / \mathrm{L})$, dissolved oxygen (DO) $(7.65 \pm 1.07 \mathrm{mg} / \mathrm{L}, 7.43 \pm 0.88 \mathrm{mg} / \mathrm{L})$ from station 2 and 3 respectively; $\mathrm{pH}(5.38 \pm 0.44,6.36 \pm 0.24)$ and salinity $(0.106 \pm 0.074 \mathrm{ppt}$, $0.040 \pm 0.020 \mathrm{ppt}$ ) from station 3 and 1 respectively did not show any significant difference (Table II). Station 1 contained the highest conductivity $(255.10 \pm 45.41 \mu \mathrm{s} / \mathrm{cm}), \mathrm{CO}_{2}$ $(12.56 \pm 3.29 \mathrm{mg} / \mathrm{L})$, total hardness $(246.25 \pm 15.92 \mathrm{mg} / \mathrm{L})$ and chemical oxygen demand $(\mathrm{COD})$ $(184.46 \pm 15.12 \mathrm{mg} / \mathrm{L})$; but the peak biochemical oxygen demand (BOD) $(213.48 \pm 24.48 \mathrm{mg} / \mathrm{L})$ and total dissolved solid (TDS) $(147.89 \pm 8.74 \mathrm{mg} / \mathrm{L})$ was obtained in station 3 . On the other hand, the highest $\mathrm{pH}(7.52 \pm 0.88)$, salinity $(14.28 \pm 1.18 \mathrm{ppt})$, temperature $\left(28.20 \pm 1.25^{\circ} \mathrm{C}\right)$ and alkalinity $(80.44 \pm 6.02 \mathrm{mg} / \mathrm{L})$ were obtained from station 2 . 
GABRIEL OLARINDE MEKULEYI et al.

Table I. Comparison of heavy metals concentration in water sample from the three creeks

\begin{tabular}{lccc}
\hline Heavy Metals & Station 2 & Station 3 & Station 1 \\
\hline $\mathrm{Cd}(\mathrm{mg} / \mathrm{kg})$ & $0.100 \pm 0.004^{\mathrm{a}}$ & $0.008 \pm 0.005^{\mathrm{a}}$ & $0.004 \pm 0.001^{\mathrm{a}}$ \\
$\mathrm{Cr}(\mathrm{mg} / \mathrm{kg})$ & $0.008 \pm 0.003^{\mathrm{a}}$ & $0.013 \pm 0.009^{\mathrm{a}}$ & $0.006 \pm 0.004^{\mathrm{a}}$ \\
$\mathrm{Cu}(\mathrm{mg} / \mathrm{kg})$ & $0.39 \pm 0.74^{\mathrm{a}}$ & $0.60 \pm 0.47^{\mathrm{a}}$ & $0.41 \pm 0.18^{\mathrm{a}}$ \\
$\mathrm{Fe}(\mathrm{mg} / \mathrm{kg})$ & $1.23 \pm 0.39^{\mathrm{a}}$ & $1.48 \pm 0.45^{\mathrm{a}}$ & $1.65 \pm 0.35^{\mathrm{a}}$ \\
$\mathrm{Cu}(\mathrm{mg} / \mathrm{kg})$ & $0.39 \pm 0.74^{\mathrm{a}}$ & $0.60 \pm 0.47^{\mathrm{a}}$ & $0.41 \pm 0.18^{\mathrm{a}}$ \\
$\mathrm{Zn}(\mathrm{mg} / \mathrm{kg})$ & $0.86 \pm 0.36^{\mathrm{a}}$ & $1.38 \pm 0.49^{\mathrm{a}}$ & $0.69 \pm 0.26^{\mathrm{a}}$ \\
$\mathrm{Pb}(\mathrm{mg} / \mathrm{kg})$ & $0.083 \pm 0.050^{\mathrm{a}}$ & $0.175 \pm 0.162^{\mathrm{a}}$ & $0.058 \pm 0.043^{\mathrm{a}}$ \\
\hline
\end{tabular}

Mean \pm SD values with same superscript in the row are not significantly $(p>0.05)$ different.

Station $1=$ Badagry Creek, Station $2=$ Tomaro creek and Station 3= Ajegunle creek

Table II. Physico-chemical parameters of the sampled creeks in Lagos, Nigeria

\begin{tabular}{lccc}
\hline Parameters & Station 2 & Station 3 & Station 1 \\
\hline Conductivity $(\mu \mathrm{s} / \mathrm{cm})$ & $152.87 \pm 25.60^{\mathrm{a}}$ & $210.28 \pm 31.57^{\mathrm{b}}$ & $255.10 \pm 45.41^{\mathrm{c}}$ \\
TDS $(\mathrm{mg} / \mathrm{L})$ & $138.49 \pm 11.25^{\mathrm{a}}$ & $147.89 \pm 8.74^{\mathrm{b}}$ & $144.97 \pm 10.38^{\mathrm{c}}$ \\
$\mathrm{CO} 2(\mathrm{mg} / \mathrm{L})$ & $8.12 \pm 1.64^{\mathrm{a}}$ & $7.48 \pm 2.15^{\mathrm{a}}$ & $12.56 \pm 3.29^{\mathrm{b}}$ \\
Total Hardness $(\mathrm{mg} / \mathrm{L})$ & $214.48 \pm 3.46^{\mathrm{a}}$ & $196.45 \pm 8.89^{\mathrm{b}}$ & $246.25 \pm 15.92^{\mathrm{c}}$ \\
COD $(\mathrm{mg} / \mathrm{L})$ & $61.62 \pm 12.34^{\mathrm{a}}$ & $168.41 \pm 22.63^{\mathrm{b}}$ & $184.46 \pm 15.12^{\mathrm{c}}$ \\
Alkalinity $(\mathrm{mg} / \mathrm{L})$ & $80.44 \pm 6.02^{\mathrm{a}}$ & $37.64 \pm 3.66^{\mathrm{b}}$ & $32.55 \pm 4.82^{\mathrm{c}}$ \\
Temperature $\left({ }^{\mathrm{O}} \mathrm{C}\right)$ & $28.20 \pm 1.25^{\mathrm{a}}$ & $25.59 \pm 1.99^{\mathrm{b}}$ & $26.73 \pm 1.85^{\mathrm{c}}$ \\
BOD $(\mathrm{mg} / \mathrm{L})$ & $20.98 \pm 4.84^{\mathrm{a}}$ & $213.48 \pm 24.48^{\mathrm{b}}$ & $209.80 \pm 28.17^{\mathrm{c}}$ \\
DO $(\mathrm{mg} / \mathrm{L})$ & $7.65 \pm 1.07^{\mathrm{a}}$ & $7.43 \pm 0.88^{\mathrm{a}}$ & $5.87 \pm 0.84^{\mathrm{b}}$ \\
pH(mg/L) & $7.52 \pm 0.88^{\mathrm{a}}$ & $5.38 \pm 0.44^{\mathrm{b}}$ & $6.36 \pm 0.24^{\mathrm{b}}$ \\
Salinity(ppt) & $14.28 \pm 1.18^{\mathrm{a}}$ & $0.106 \pm 0.074^{\mathrm{b}}$ & $0.040 \pm 0.020^{\mathrm{b}}$ \\
\hline
\end{tabular}

Mean \pm SD values with same superscript in the row are not significantly $(p>0.05)$ different.

Station $1=$ Badagry Creek, Station $2=$ Tomaro creek and Station $3=$ Ajegunle creek

Sampling station 2 had the lowest conductivity $(152.87 \pm 25.60 \mu \mathrm{s} / \mathrm{cm})$, TDS $(138.49 \pm 11.25 \mathrm{mg} / \mathrm{L})$, COD $(61.62 \pm 12.34 \mathrm{mg} / \mathrm{L})$ and BOD $(20.98 \pm 4.84 \mathrm{mg} / \mathrm{L})$. However, station 1 had the lowest DO $(5.87 \pm 0.84 \mathrm{mg} / \mathrm{L})$, salinity $(0.040 \pm 0.020 \mathrm{ppt})$ and alkalinity $(32.55 \pm 4.82 \mathrm{mg} / \mathrm{L})$, while the lowest $\mathrm{CO}_{2}(7.48 \pm 2.15 \mathrm{mg} / \mathrm{L})$, temperature $\left(25.59 \pm 1.99^{\circ} \mathrm{C}\right)$, and $\mathrm{pH}(5.38 \pm 0.44)$ were recorded in station 3 .

Comparison of heavy metals in $C$. filamentosus, $K$. nana and P. lascaris: In comparison of the metals in fish, the results showed that values of copper, chromium, cadmium and lead in the three sampled fishes are not different $(p>0.05)$ across the sampling stations. Iron content in $C$. filamentosus $(11.57 \pm 2.50 \mathrm{mg} / \mathrm{kg})$ from station 3 was significantly $(p<0.05)$ higher than iron content recorded from station $2(6.54 \pm 2.88 \mathrm{mg} / \mathrm{kg})$ (Table III). Similarly, iron content in $K$. nana $(8.34 \pm 1.10 \mathrm{mg} / \mathrm{kg})$ from station 3 is higher than that from station $1(6.12 \pm 1.04 \mathrm{mg} / \mathrm{kg})$ and station $2(3.62 \pm 1.14 \mathrm{mg} / \mathrm{kg})$. In like manner, value of $\mathrm{Zn}(5.54 \pm 1.12 \mathrm{mg} / \mathrm{kg})$ in $C$. filamentosus recorded from station 3 was significantly $(p<0.05)$ higher than that from station 2 $(2.45 \pm 0.96 \mathrm{mg} / \mathrm{kg})$ and station $1(3.84 \pm 0.86 \mathrm{mg} / \mathrm{kg})$.

Comparison of length-weight relationship, condition factor and Hazard Index of the sampled fishes: Only $C$. filamentosus from station 2 exhibited positive allometry whose b value was 3.10. All the $\mathrm{R}^{2}$ values of the examined fish species are below 1.0 while mean condition 
COMPARATIVE ASSESSMENT OF WELL-BEING OF $C$. FILAMENTOSUS, $K$. NANA AND

P. LASCARIS FROM TOMARO, AJEGUNLE AND BADAGRY CREEKS IN LAGOS, NIGERIA

factors (K) of the fish species was between 0.68 (in $C$.filamentosus from station 3) and 1.98 (in $K$. nana from station 1) (Table IV). The mean body weight of $C$. filamentosus significantly $(p<0.05)$ differs across the three creeks with the highest mean body weight $(26.84 \pm 4.17 \mathrm{~g})$ recorded in station 2 and least $(19.65 \pm 4.06 \mathrm{~g})$ in station 1 (Table IV). The Hazard Index (HI) of $C$. filamentosus from stations 2,3 and 1 respectively are $1.18,2.06$ and 1.81 respectively. The HI values calculated for $K$. nana are $0.63,1.42$ and 1.05 from station 2,3 and 1 respectively, while $\mathrm{HI}$ of $0.72,0.02$ and 0.59 were calculated for $P$. lascaris collected from stations 2, 3 and 1 respectively (Table IV).

Table III. Comparison of heavy metal contents $(\mathrm{mg} / \mathrm{kg})$ in fish species from the three creeks

\begin{tabular}{|c|c|c|c|c|c|c|c|}
\hline Location & Fish Species & $\mathrm{Cd}$ & $\mathrm{Cr}$ & $\mathrm{Cu}$ & $\mathrm{Fe}$ & $\mathrm{Pb}$ & $\mathrm{Zn}$ \\
\hline \multirow[t]{3}{*}{ Station 2} & C.filamentosus & $\begin{array}{c}0.002 \pm \\
0.001\end{array}$ & $\begin{array}{c}0.42 \pm \\
0.01\end{array}$ & $\begin{array}{c}0.18 \pm \\
0.06\end{array}$ & $\begin{array}{l}6.54 \pm \\
2.88^{b}\end{array}$ & $\begin{array}{c}0.56 \pm \\
0.03\end{array}$ & $\begin{array}{c}2.45 \pm \\
0.96^{\mathrm{b}}\end{array}$ \\
\hline & K. nana & $\begin{array}{c}0.001 \pm \\
0.001\end{array}$ & $\begin{array}{c}0.01 \pm \\
0.01\end{array}$ & $\begin{array}{c}0.04 \pm \\
0.01\end{array}$ & $\begin{array}{c}3.62 \pm \\
1.14^{\mathrm{c}}\end{array}$ & $\begin{array}{c}0.36 \pm \\
0.01\end{array}$ & $\begin{array}{l}1.48 \pm \\
0.22^{\mathrm{c}}\end{array}$ \\
\hline & P. lascaris & $\begin{array}{c}0.000 \pm \\
0.000\end{array}$ & $\begin{array}{c}0.00 \pm \\
0.00\end{array}$ & $\begin{array}{c}0.02 \pm \\
0.01\end{array}$ & $\begin{array}{l}4.20 \pm \\
0.32^{\mathrm{d}}\end{array}$ & $\begin{array}{c}0.30 \pm \\
0.01\end{array}$ & $\begin{array}{l}1.32 \pm \\
0.11^{\mathrm{d}}\end{array}$ \\
\hline \multirow[t]{3}{*}{ Station 3} & C.filamentosus & $\begin{array}{c}0.105 \pm \\
0.002\end{array}$ & $\begin{array}{c}0.33 \pm \\
0.01\end{array}$ & $\begin{array}{c}0.55 \pm \\
0.36\end{array}$ & $\begin{array}{c}11.57 \pm \\
2.50^{\mathrm{ab}}\end{array}$ & $\begin{array}{c}0.53 \pm \\
0.02\end{array}$ & $\begin{array}{l}5.45 \pm \\
1.12^{\mathrm{ab}}\end{array}$ \\
\hline & K. nana & $\begin{array}{c}0.004 \pm \\
0.001\end{array}$ & $\begin{array}{c}0.00 \pm \\
0.00\end{array}$ & $\begin{array}{c}0.22 \pm \\
0.02\end{array}$ & $\begin{array}{l}8.34 \pm \\
1.10^{\mathrm{ac}}\end{array}$ & $\begin{array}{c}0.32 \pm \\
0.01\end{array}$ & $\begin{array}{r}2.18 \pm \\
1.10^{c}\end{array}$ \\
\hline & P. lascaris & $\begin{array}{c}0.001 \pm \\
0.001\end{array}$ & $\begin{array}{c}0.00 \pm \\
0.00\end{array}$ & $\begin{array}{c}0.00 \pm \\
0.00\end{array}$ & $\begin{array}{r}5.18 \pm \\
1.20^{\mathrm{d}}\end{array}$ & $\begin{array}{c}0.14 \pm \\
0.01\end{array}$ & $\begin{array}{l}1.58 \pm \\
0.95^{\mathrm{d}}\end{array}$ \\
\hline \multirow[t]{3}{*}{ Station 1} & C.filamentosus & $\begin{array}{c}0.008 \pm \\
0.002\end{array}$ & $\begin{array}{c}0.03 \pm \\
0.01\end{array}$ & $\begin{array}{c}0.78 \pm \\
0.03\end{array}$ & $\begin{array}{c}10.65 \pm \\
2.42^{\mathrm{ab}}\end{array}$ & $\begin{array}{c}0.26 \pm \\
0.02\end{array}$ & $\begin{array}{l}3.84 \pm \\
0.86^{\mathrm{bb}}\end{array}$ \\
\hline & K. nana & $\begin{array}{c}0.001 \pm \\
0.001\end{array}$ & $\begin{array}{c}0.01 \pm \\
0.01\end{array}$ & $\begin{array}{c}0.34 \pm \\
0.02\end{array}$ & $\begin{array}{l}6.12 \pm \\
1.04^{\mathrm{bc}}\end{array}$ & $\begin{array}{c}0.18 \pm \\
0.01\end{array}$ & $\begin{array}{c}1.39 \pm \\
0.92^{\mathrm{c}}\end{array}$ \\
\hline & P. lascaris & $\begin{array}{r}0.001 \pm \\
0.001^{\mathrm{a}}\end{array}$ & $\begin{array}{c}0.01 \pm \\
0.01\end{array}$ & $\begin{array}{c}0.17 \pm \\
0.01\end{array}$ & $\begin{array}{r}3.48 \pm \\
1.12^{\mathrm{d}}\end{array}$ & $\begin{array}{c}0.11 \\
\pm 0.01\end{array}$ & $\begin{array}{l}1.28 \pm \\
0.64^{\mathrm{d}}\end{array}$ \\
\hline
\end{tabular}

Mean \pm SD values with no superscript/ same in the row $=$ not significant $(p>0.05)$ difference.

Mean \pm SD values with different superscript in the row $=$ significant $(p<0.05)$ difference.

Station $1=$ Badagry Creek, Station $2=$ Tomaro creek and Station $3=$ Ajegunle creek

Table IV. Length-weight relationship, K and HI of fish species collected from the three creeks

\begin{tabular}{lllccrrr}
\hline Creek(s) & Species & $\begin{array}{c}\text { Mean Total } \\
\text { Length(cm) }\end{array}$ & $\begin{array}{c}\text { Mean Body } \\
\text { Weight }(\mathrm{g})\end{array}$ & $\mathrm{K}$ & $\mathrm{R}^{2}$ & $\mathrm{~b}$ & $\mathrm{HI}$ \\
\hline Station 2 & $\begin{array}{l}\text { Chrysichthys } \\
\text { filamentosus }\end{array}$ & $16.58 \pm 2.15$ & $26.84 \pm 4.17$ & 1.28 & 0.80 & 3.10 & 1.18 \\
Station 3 & C.filamentosus & $15.78 \pm 1.69$ & $22.86 \pm 2.34$ & 0.68 & 0.69 & 1.84 & 2.06 \\
Station 1 & C.filamentosus & $14.26 \pm 1.57$ & $19.65 \pm 4.06$ & 1.45 & 0.54 & 0.31 & 1.81 \\
Station 2 & Kribia nana & $11.46 \pm 0.29$ & $13.48 \pm 0.46$ & 1.86 & 0.28 & 0.64 & 0.63 \\
Station 3 & K. nana & $10.72 \pm 0.66$ & $12.44 \pm 0.57$ & 1.76 & 0.25 & 0.59 & 1.42 \\
Station 1 & K. nana & $10.50 \pm 0.47$ & $12.11 \pm 0.42$ & 1.98 & 0.32 & 0.54 & 1.05 \\
Station 2 & P. lascaris & $13.45 \pm 0.65$ & $14.49 \pm 1.26$ & 1.35 & 0.14 & 0.26 & 0.72 \\
Station 3 & P. Lascaris & $12.52 \pm 0.86$ & $13.98 \pm 1.30$ & 0.88 & 0.27 & 0.16 & 0.02 \\
Station 1 & P. lascaris & $12.52 \pm 0.86$ & $13.94 \pm 1.50$ & 0.99 & 0.17 & 0.18 & 0.59 \\
\hline $\mathrm{R}^{2}=$ Coefficient of determination, b= slope of regression line, K= condition factor, HI= hazard index; Station $1=$ \\
Badagry Creek, Station 2= Tomaro creek and Station 3= Ajegunle creek
\end{tabular}


GABRIEL OLARINDE MEKULEYI et al.

Comparison of heavy metal content in sediment across the creeks: The copper content in the sediment from stations 2 and 1 were significantly lower than that obtained at station 3 $(10.88 \pm 3.54 \mathrm{mg} / \mathrm{kg})$. The lead values $(1.16 \pm 0.14 \mathrm{mg} / \mathrm{kg})$ in sediment from station 1 was significantly lower than lead recorded from both station 2 and 3 . On the opposite, the values of iron and zinc in the sediment from the three creeks significantly $(\mathrm{p}<0.05)$ differs but values of cadmium and chromium was not different $(p>0.05)$ (Table V).

Table V. Comparison of heavy metals concentration in sediment from the three creeks

\begin{tabular}{lccc}
\hline Heavy Metals & Station 2 & Station 3 & Station 1 \\
\hline $\mathrm{Cd}(\mathrm{mg} / \mathrm{kg})$ & $0.97 \pm 0.12^{\mathrm{a}}$ & $1.64 \pm 0.62^{\mathrm{a}}$ & $0.88 \pm 0.37^{\mathrm{a}}$ \\
$\mathrm{Cr}(\mathrm{mg} / \mathrm{kg})$ & $1.64 \pm 0.86^{\mathrm{a}}$ & $1.75 \pm 0.26^{\mathrm{a}}$ & $1.24 \pm 0.42^{\mathrm{a}}$ \\
$\mathrm{Cu}(\mathrm{mg} / \mathrm{kg})$ & $8.19 \pm 4.26^{\mathrm{a}}$ & $10.88 \pm 3.54^{\mathrm{b}}$ & $7.74 \pm 1.70^{\mathrm{a}}$ \\
$\mathrm{Fe}(\mathrm{mg} / \mathrm{kg})$ & $527.14 \pm 89.67^{\mathrm{a}}$ & $1432.24 \pm 116.23^{\mathrm{b}}$ & $1164.02 \pm 84.62^{\mathrm{c}}$ \\
$\mathrm{Zn}(\mathrm{mg} / \mathrm{kg})$ & $11.28 \pm 3.44^{\mathrm{a}}$ & $20.94 \pm 2.66^{\mathrm{b}}$ & $13.74 \pm 1.27^{\mathrm{c}}$ \\
$\mathrm{Pb}(\mathrm{mg} / \mathrm{kg})$ & $4.18 \pm 2.36^{\mathrm{a}}$ & $3.44 \pm 1.05^{\mathrm{a}}$ & $1.16 \pm 0.14^{\mathrm{b}}$ \\
\hline
\end{tabular}

Mean \pm SD values with same superscript in the row are not significantly $(p>0.05)$ different.

Station $1=$ Badagry Creek, Station $2=$ Tomaro creek and Station $3=$ Ajegunle creek

Pollution Index Model: The EF values for station 3 are: 0.622, 0.393, 0.489, 1.000, 0.303 and 0.683 for cadmium, copper, iron, lead and zinc respectively. On the other hand, values of $0.334,0.278,0.348,1.000,0.102$ and 0.448 were calculated for cadmium, chromium, copper, iron, lead and zinc respectively from station 1 . The highest Igeo value recorded at stations 2, 3 and 1 respectively was for cadmium whose values are $(0.649,1.097$ and 0.589$)$ respectively. On the contrast, the lowest IgEo values recorded in stations 2,3 and 1 respectively are iron (0.002), lead (0.035) and lead (0.012). The peak CF and Er respectively was obtained in cadmium and their values were $(1.213,36.390)$ at station $2,(2.050,61.50)$ at station 3 and $(1.100,33.000)$ at station 1 (Table VI). Station 2 was the control sites with constant EF values for all the metals.

Table VI. CF, EF, IGEO and Er in sediment from the three Creeks in Lagos, Nigeria

\begin{tabular}{llcccccc}
\hline Location & Ecological Index & $\mathrm{Cd}$ & $\mathrm{Cr}$ & $\mathrm{Cu}$ & $\mathrm{Fe}$ & $\mathrm{Pb}$ & $\mathrm{Zn}$ \\
\hline Station 2 & EF & 1.000 & 1.000 & 1.000 & 1.000 & 1.000 & 1.000 \\
& IGEO & 0.649 & 0.004 & 0.037 & 0.002 & 0.042 & 0.024 \\
& $\mathrm{CF}$ & 1.213 & 0.016 & 0.228 & 0.014 & 0.049 & 0.081 \\
& Er & 36.390 & 0.032 & 1.140 & $\mathrm{NA}$ & 0.245 & 0.081 \\
\hline Station 3 & EF & 0.622 & 0.393 & 0.489 & 1.000 & 0.303 & 0.683 \\
& IGEO & 1.097 & 0.004 & 0.049 & 0.006 & 0.035 & 0.044 \\
& $\mathrm{CF}$ & 2.050 & 0.018 & 0.302 & 0.038 & 0.040 & 0.150 \\
& Er & 61.50 & 0.036 & 1.510 & $\mathrm{NA}$ & 0.200 & 0.150 \\
\hline Station 1 & EF & 0.334 & 0.278 & 0.348 & 1.000 & 0.102 & 0.448 \\
& IGEO & 0.589 & 0.003 & 0.035 & 0.005 & 0.012 & 0.029 \\
& CF & 1.100 & 0.012 & 0.215 & 0.031 & 0.014 & 0.098 \\
& Er & 33.000 & 0.024 & 1.075 & NA & 0.070 & 0.098 \\
\hline CF $=$ Contamination Factor, EF $=$ Enrichment Factor, IGEO $=$ Geochemical Accumulation (IGEO) and Er $=$
\end{tabular}

Ecological Risk Factor. Station 1= Badagry Creek, Station 2= Tomaro creek and Station 3= Ajegunle creek 
COMPARATIVE ASSESSMENT OF WELL-BEING OF $C$. FILAMENTOSUS, $K$. NANA AND

P. LASCARIS FROM TOMARO, AJEGUNLE AND BADAGRY CREEKS IN LAGOS, NIGERIA

\section{Discussion}

The biological, chemical and physical parameters of water affect the desirability of water for any specific use (Boyd 1982). Anyanwu (2012) explained that quality of any water body is controlled by its physical, chemical and heavy metal factors. For the present study, most of the water quality parameters were very conducive for the fish when compared to WHO (2004) and FEPA (2007) permissible limits. Studies have shown that dissolved oxygen (DO) is an important factor limiting abundance, distribution, composition and survival of aquatic organisms (Etim et al. 2013). DO tends to reduce in concentration when effluents containing cations compete for binding sites with the hydroxyl group in water molecule to form other compounds thereby depleting the water body of its dissolved oxygen (Pollock et al. 2007). According to Okorafor et al. (2013), DO level of 1 to $5 \mathrm{mg} / \mathrm{L}$ will slow down the growth of fishes when continuously exposed, while levels below $1 \mathrm{mg} / \mathrm{L}$ are reportedly fatal to fish when exposed for more than a few hours. Water parameters such as alkalinity, hardness, BOD, conductivity and COD in this study were lower than that reported in Owudu creek in Niger Delta, Nigeria and in Gangetic Delta Region, West Bengal, India respectively (Friday et al. 2013). However, the water parameters reported from River Okpokwu in Benue State, Nigeria was higher than that obtained in this study.

Different authors have highlighted the importance of different water physico-chemical parameters. For instance, Ajit and Padmakar (2012) and Ani et al. (2016) reported that water temperature controlled the metabolism and physiology of fishes as well as its productivity. Kara et al. (2004) revealed that temperature above $30^{\circ} \mathrm{C}$ can cause regression in growth of aquatic organisms and decay in plants. Lawson (2011) disclosed that higher temperature increases toxicity of pesticides and heavy metals, and susceptibility of organisms to toxicants. Temperature is known to impact several chemical and biological characteristics and greatly influence DO, Alkalinity, EC and pH (Matta et al. 2017). As defined by Ekpo et al. (2012), conductivity is a measure of the total amount of ions present in a water body which is useful in approximating the chemical richness of the water. Alkalinity is important to fish and aquatic life because it buffers against rapid $\mathrm{pH}$ changes. Total dissolved solids (TDS) is described as the total amount of mobile charged ions, including minerals, salts or metals dissolved in a given volume of water in $\mathrm{mg} / \mathrm{L}$.TDS in aquatic systems may be related to the geo-chemistry of the system and the allochthonous load it carries and constitute an important parameter in describing the chemical density of water as a fitness factor (Taskeena et al. 2017).

Biochemical Oxygen Demand (BOD) is the amount of oxygen utilized by microorganisms in stabilizing organic matter (Ewebiyi et al. 2015). They asserted that unpolluted waters usually have BOD value of $2.00 \mathrm{mg} / \mathrm{L}$ or less, while those receiving wastewaters may have value as high as $10 \mathrm{mg} / \mathrm{L}$. Turbidity is a measure of the reduction of transparency due to dissolved and suspended particulate matter in the water column (Matta et al. 2017). Water hardness is not a pollution parameter but represents the quality of water in terms of calcium, magnesium, carbonate, sulphate, chlorate and nitrate (Matta et al. 2017) and water quality with less than $75 \mathrm{mg} / \mathrm{L}$ of $\mathrm{CaCO}_{3}$ is considered soft, while above $75 \mathrm{mg} / \mathrm{L}$ of $\mathrm{CaCO}_{3}$ is hard water. Therefore, it's cleared that the three creeks examined in this present study are hard waters. 
In the present study, all metals in water samples (except lead and cadmium) were within the standard limits. El-Sayed et al. (2011) have reported that though heavy metals are natural constituents of the Earth's crust however they can bio-accumulate along the food chain in soils, water and sediment causing different types of ailments and diseases. C. filamentosus and $K$. nana from the three creeks contained lead, cadmium, iron concentrations that were above the standard permissible limit. Similarly, $C$. filamentosus collected from stations 1 and 3 consist of chromium and copper level that exceeded recommended limits in fish. Range of recommended standard permissible limits of metals such as zinc ,lead , copper ,iron, cadmium and chromium, in fish has been documented (WHO 2003). The present findings as regard metal concentration in fish is similar to the record of metals in $C$. nigrodigitatus from Ibaka and Ifiayong fishing sites in Akwa Ibom State, Nigeria (Akpanyung et al. 2014) but exceeded that which was recorded in E. fimbriata from Cross River Estuary (Udo and Ndunobong 2016). However, all the metals obtained in fish during this study was lower than that reported in Clarias gariepinus and Oreochromis niloticus (Ejike and Liman 2017). Various deleterious effects of high concentration of heavy metals in fish have been reported in literatures such as Mekuleyi et al. (2019) and Duruibe et al. (2007).

The assessment of concentrations of metals in the sediments during this present study revealed that content of iron and lead was not below the USEPA (2018) recommended maximum permissible limit. Contrary to the present findings, Okorafor et al., (2013) found out that all metals examined in sediment from Intertidal Regions of Calabar River were within permissible limits. They attributed this outcome to tidal influence which resulted in thorough mixing of the effluent in the large water body and thus minimizing the impact on the receiving water body. Mekuleyi et al. (2019) opined that sources of lead and iron pollution in water sediment include metallic pipes, batteries of pumping equipment, automobile emissions, as well as drainage of lead compounds from crop farms treated with agro-chemicals. The values of ecological risk factor (Er) for cadmium and copper (at stations 1 and 2), and copper (at station 3 ) in this study indicated low potential ecological risk of the habitats. However, the Er value recorded for cadmium in station 3 implies moderate potential ecological risk. Comparatively, all the Er values in this study were below that reported by Hashim et al. (2015). The values for enrichment factors in this study indicate that there is a minimal enrichment of the metals in the sediments. Okorafor et al. (2013) have reported similar results. However, Igbinosa et al. (2012) which work on Shanomi Creek in Niger Delta reported EF value that was lower than what was recorded in this study. Furthermore, the values of contamination factor (CF) and Igeo values for this study indicated that the sediment was moderately contaminated. Apart from $C$. filamentosus and $P$. lascaris in station 3 and $P$. lascaris in station 1 most of the fish sampled in this study had mean $\mathrm{K}>1$ and this means that they are in good state and condition in their respective habitats. Similar findings of fish with $\mathrm{k}$ factor above 1 has been reported by Imam et al. (2010), Ahmed et al. (2011), and Kumolu-Johnson and Ndimele (2011). Majority of the fish had negative allometry growth pattern and this indicated that the fish becomes thinner with increase in length (King 2007). The HI content in $C$. filamentosus from the three creeks and $K$. nana from stations 1 and 3 was higher than 1 . According to Zodape (2014), HI value that is above 1 poses public health concern. Therefore, the implication of HI values exceeding 1 in this study is that consumption of large quantity of the fish species by individual person could lead to health problem as opined by Zodape (2014). 
From the findings in this study, it could be concluded that the three habitats (creeks) are suitable for the fish, although the creeks are contaminated with low levels of heavy metals. More so, the values of the condition factors implied that the fish are in good status while most of them exhibited negative allometric growth pattern. However, HI index divulged that high health risk may occur if human consume large quantity of the sampled fish species.

\section{Literature Cited}

Ahmed, E.O., M.E. Ali and A.A. Aziz, 2011. Length-weight relationships and condition factors of six fish species in Atbara River and Khashm el- girba Reservoir, Sudan. Int. J. Agric. Sci., 3(1): 65-70.

Ajit, M.K. and A.S. Padmakar, 2012. Determination of physio-chemical parameters of DeoliBhorus Dam Water. Adv. Appl. Sci. Res., 3(1): 273-279.

Akpanyung, E.O., M.E. Udoudo, I.A. Ekam and O.A. Ngozi, 2014. Levels of heavy metals in fish obtained from two fishing sites in Akwa Ibom State, Nigeria. Afr. J. Environ. Sci. Technol., 8(7): $16-21$.

Ali, M. and V.T.B. Hau, 2001. Vegetables in Bangladesh: Economic and nutritional impact of new varieties and technologies. Asian Vegetable Research and Development Centre, Technical Bulletin No. 25 AVRDC, Taiwan.

Ani, C., O.I. Okogwu, G.N. Nwonumara, C.D. Nwani and A.I. Nwinyimagu, 2016. Evaluation of physio-chemical parameters of selected Rivers in Ebonyi State Southeast, Nigeria. Green. J. Biol. Sci., 6(2): 34-41.

Anyawu, E.O., 2012. Physio-chemical and some trace metal analysis of Ogba River, Benin City, Nigeria. Jordan J. Biol. Sci., 5(1): 47-54.

APHA (American Public Health Association), 1998. Standard methods for the examination of water and waste water. 14th edition, Washington DC. pp 1007-1157.

Boyd, C.E., 1982. Water quality management for pond fish culture. Aquac. Fish. Sci., 9: 34- 44.

Copat, C., F. Bella, M. Castaing, R. Fallico, S. Sciacca and M. Ferrante, 2012. Heavy metals concentrations in fish from Sicily (Mediterranean Sea) and evaluation of possible health risks to consumers. Bull. Environ. Contam. Toxicol., 88: 78-83.

Duruibe, J.O., M.O.C. Ogwuegbu and J.N. Egwurugwu, 2007. Heavy metal pollution and human biotoxic effects. Int. J. Physic. Sci., 2 (5): 112-118.

Ejike, L.O. and M.G. Liman, 2017. Determination of heavy metals in selected fish species found in Kwalkwalara River, Dundaye, Sokoto State. IOSR J. Appl. Chem., 10(1): 38-42.

Ekpo, I.E., L.A. Chude, G.C. Onuoha and J.P. Udoh, 2012. Studies on the physico-chemical characteristics and nutrients of a tropical rainforest river in southeast Nigeria. Aquac. Aquar. Conserv. Legis. Int. J. Bioflux Soc., 5(3): 142-162.

El-sayed, E.A., M.S. El-Ayyat, N. El-Sayed and Z.Z.K. Khater, 2011. Assessment of heavy metals in water, sediment and Fish tissues, from Sharkia Province, Egypt. Egypt. J. Aquat. Biol. Fish., 15(2): $125-144$

Etim, E.E., R. Odoh, A.U. Hodo, S.D. Umoh, and U. Lawal, 2013. Water quality index for the assessment of water quality from different sources in the Niger Delta Region of Nigeria. Front. Sci., 3(3): 89-95.

Ewebiyi, F.O., J. Appah and G.A. Ajibade, 2015. Contribution of physic-chemical parameters of water bodies to taxanomy, distribution and diversity of phytoplankton within Kaduna metropolis, Nigeria. $J$. Environ. Health Sci., 5(18): 20-28.

FEPA (Federal Protection Agency), 2007. National Guidelines and Standard for Water Quality in Nigeria. FEPA, Lagos, Nigeria, 114p.

Friday, U.O., A.F. Wokoma, and A.J. Edoghotu, 2013. Levels of bioaccumulation of some heavy metals in fish (Tilapia zilli) and their concentration in water and sediment of Owudu creek, Niger Delta, Nigeria. Resour. Environ., 3: 59-64. 
GABRIEL OLARINDE MEKULEYI et al.

Guerra, K., J. Konz, K. Lisi and C. Neebrem, 2010. Exposure Factors handbook. USEPA, Washington D.C.

Håkanson, L., 1980. An Ecological Risk Index for Aquatic Pollution Control: A Sedimentological Approach. Wat. Res., 14: 975-1001.

Hashim, M., G.N.N., Jafaru, A.A. Thomas, E.K. Nartey, P.M. Nude and N. Dora, 2015. Geochemical Assessment of heavy metal pollution as impacted by municipal solid waste at Abloradjei Waste Dump Site, Accra-Ghana. Res. J. Environ. Earth Sci., 7(3): 50-59.

Igbinosa, E.O., O.O. Uyi, E.E. Odjadjare, C.U. Ajuzie, P.O. Orhue and E.M. Adewole, 2012. Assessment of physio-chemical qualities, heavy metal concentrations and bacterial pathogens in Shanomi Creek in the Niger Delta, Nigeria. Afr. J. Environ. Sci. Technol., 6(II): 419-424.

Imam, T.S., U. Bala, M.L. Balarabe and T.I. Oyeyi, 2010. Length-weight relationship and condition factor of four fish species from Wasai Reservoir in Kano, Nigeria. Afr. J. Gen. Agric., 6(3): 125130.

Kara, Y., I. Kara and D. Basaran, 2004. Investigation of some physical and chemical characteristics of water in the lake Isykli in Denizli, Turkey. Int. J. Agric. Biol., 6(2): 275-277.

King, R.P., 2007. Length-weight relationship of Nigeria freshwater fishes. Naga ICLARM Quart. 19(3): 49-52.

Kumolu-Johnson, C.A. and P.E. Ndimele, 2011. Length-weight relationships of nine fish species from Badagry creek, Lagos, Nigeria. Afr. J. Biotechnol., 10(2): 241-243.

Kumolu-Johnson, C.A., P.E. Ndimele, S.L. Akintola and C.C. Jibuike, 2010. Copper, zinc and iron concentrations in water, sediment and Cynothrissa mento (Regan 1917) from Ologe Lagoon, Lagos, Nigeria: A preliminary survey. Afr. J. Aquat. Sci., 35: 87-94.

Lawson, E.O., 2011. Physico-chemical parameters and heavy metal contents of water from the mangrove swamps of Lagos Lagoon, Lagos, Nigeria. Biol. Resou., 5(1): 08-21.

Matta, G., S. Srivastava, R.R. Pandey and K.K. Saini, 2017. Assessment of physico-chemical characteristics of Ganga Canal water quality in Uttarakhand. Environ Dev. Sustain., 19: 419-431.

Mekuleyi, G.O., M.A. Anetekhai, O.J. Aderinola and A.A. Adu, 2019. Environmental Health Status of Some Aquatic Ecosystems in Badagry Division of Lagos State, Southwest, Nigeria. Int. J. Ecotoxicol. Ecobiol., 4(4): 93-102.

Ndimele, P.E., 2012. The effects of water hyacinth (Eichhornima crassipes) infestation on the physicochemsitry, nutrients and heavy metal content of Badagry Creek and Ologe Lagoon, Lagos. Nigeria. $J$. Environ. Sci., (2):128-136.

Nwankwo, D.I., T.A. Adesalu, C.C. Amako, S.C. Akagha, and J.D. Keyede, 2013. Temporal variations in water chemistry and chlorophyll-a at the Tomaro creek Lagos, Nigeria. J. Ecol. Nat. Environ., 5(7): $145-151$.

Okorafor, K.A., E.O. Effanga, A.B. Andem, U.U. George and D.I. Amos, 2013. Spatial variation in physical and chemical parameters and macroinvertebrates in the intertidal regions of Calabar River, Nigeria. Green. J. Geol. Earth Sci., 1(2): 063-072.

Olowu, R.A., O.O. Ayejuyo, G.O. Adewuyi, A.O. Babatunde, L.A. Adejoro, A.A.B. Denloye and A.L. Ogundajo, 2010. Heavy metals in fish tissue, water, sediment from Epe and Badagry Lagoons in Nigeria. E-J. Chem., 7(1): 215-221.

Pauly, D., (1983). Some simple methods for the assessment of tropical fish stocks. FAO Fish. Tech. Pap. (234) 52p.

Pollock, M.S., L.M.J. Clarke and M.G. Duber, 2007. The Effects of hypoxia on fishes: from ecological relevance to physiological effects. Environ. Rev., 15: 1-14.

Taskeena, H., P. Saltanat, N.B. Bilal and A. Uzma, 2017. Seasonal variation in water quality parameters of River Yamuna, India. Int. J. Curr. Microbio., Appl. Sci., 6(5): 694-712.

Udo, I.U. and E.I. Ndunobong, 2016. Heavy metal content of two major commercial Fish species of Cross River Estuary, Mbo Local Government Area, Akwa Ibom State, Nigeria. J. Aquat. Sci., 31(2A): 309317. 
USEPA (United States Environmental Protection Agency), 2018. Risk assessment, Regional Screening Levels (RSLs) for chemical contaminants at superfund sites-User's guide and summary generic tables.

USEPA (1989). Risk assessment Guidance for Superfund. Human Health Evaluation Manual Part A, interim final, Vol. 1. Washington DC, United States Environmental Protection Agency; EPA/540/1$89 / 002$.

Wang, X., T. Sato, B. Xing and S. Tao, 2005. Health risk of heavy metals to the general public in Tianjin, China via Consumption of vegetables and fish, Sci. Total Environ., 350: 28-37.

Wangboje, O.M. and O.T. Ekundayo, 2013. Assessment of heavy metals in surface water of the Ikoba Reservoir, Benin City, Nigeria. Nigerian J. Technol., 32 (1): 61-66.

WHO (World Health Organization), 2004. Guidelines for drinking water quality, health criteria and other supporting information. Geneva, Switzerland. $3^{\text {rd }}$ edition, Vol. 1: 1043p.

WHO (World Health Organization), 2003. List of maximum levels of heavy metals recommended for fish by the joint FAO/WHO codex Alimentaries Commission. $2^{\text {nd }}$ Edition, Rome, Italy, pp1-8.

Zodape, G.V., 2014. Metal contamination in commercially important prawns and shrimps species collected from Kolaba market of Mumbai (west coast) India. Int J. Agric Sci., 4, 160-169.

(Manuscript received: 15 May 2021) 